\title{
A note on Euroyen and domestic yen interest rates
}

\author{
Wai-Chung Lo ${ }^{a}$, Hung-Gay Fung ${ }^{b}$, Joel N. Morse ${ }^{b, *}$ \\ ${ }^{3}$ City Polytechnic of Hong Kong, 83 Tat Chee Ave, Kowloon, Hong Kong \\ 'Department of Economics and Finance, University of Baltimore, $1420 \mathrm{~N}$. Charles Street, \\ Baltimore, MD 21201, USA
}

Received August 1993; final version received February 1994

\begin{abstract}
This study examines interest rate transmission between the London Euroyen market and the Japanese domestic CD market. The results, which span 1984 through the beginning of 1993, indicate that these two interest rate series are cointegrated. In the earlier part of the sample period, causality is strongest from the Euroyen market to domestic yen interest rates. However, strong feedback effects are observed in both directions in more recent years. The use of both vector autoregressive modeling and cointegration analysis for forecasting is supported over random walk models.
\end{abstract}

JEL classification: F36; G15

Keywords: Euroyen; Rate transmission; Cointegration; Financial deregulation and forecasting

\section{Introduction}

In U.S. dollar markets, innovations in domestic interest rates lead offshore Eurodollar markets (see Fung and Isberg, 1992; Swanson, 1988; Hartman, 1984; Schnitzel, 1983; Kaen and Hachey, 1983; Giddy et al., 1979; Levin, 1974; Kwack, 1971; Hendershott, 1967). Reverse, but weaker feedback from Eurodollars to domestic markets is also observed. Are other Eurocurrencies similarly dominated

\footnotetext{
- Corresponding author.
} 
by their respective domestic money markets? To study the Japanese case, we examine interest rate transmission between Japanese domestic (CD) and offshore (Euroyen) money markets.

The Japanese market is one of the world's major financial centers. Although isolated for decades, continuing deregulation and liberalization are likely to further integrate the domestic and global markets.

We analyze the transmission of interest rate changes between the three month Japanese domestic $C D$ market and the three month Euroyen market. Specifically, we test whether interest rate innovations in these yen instruments have originated primarily in the domestic or in the offshore market. Our results contrast with the U.S. experience, where rate innovations are primarily domestic.

Daily bid rates, from November 1984 through January 1993 were obtained from Nihon Keizai Shimbun America, Inc. Data on yen interest rates prior to 1984 are not available. The vendor collected Euroyen and $C D$ rates at the end of the trading day in London and in Tokyo, respectively. CD rates reflect secondary trading in the gensaki market. ${ }^{1}$

We test whether these domestic yen and Euroyen rates are cointegrated. We also estimate an error correction model (ECM), as specified in Engle and Granger (1987) and Johansen $(1991,1988)$, in order to examine the details of the interest rate transmission mechanism.

Cointegration analysis is superior to the traditional vector autoregression (VAR) model. Time series techniques which routinely induce stationarity by taking first differences may lose information if the series are cointegrated (Granger, 1986; Engle and Granger, 1987). Thus the VAR model may be misspecified, and the use of the ECM to examine causal relationships is motivated. Earlier studies of interest rate transmission rely on the Granger-Sims causality test within a VAR context (Swanson, 1988; Hartman, 1984; Kaen and Hachey, 1983). We expand on this by analyzing the forecasting performance of both the ECM and VAR in the yen context.

The Japanese money market consists of interbank markets, in which only financial institutions participate, and open markets which have no restrictions on participation. The main interbank markets are the call market and the bill market. Open markets include the negotiable certificate of deposit (CD) market, the repurchase market, and the Treasury bill market. Further details on these markets are described more fully in McKenzie (1993), Financial Times Management Report (1993) and Takagi (1988).

The negotiable $\mathrm{CD}$ is one of the most important new instruments in the Japanese money market. After the call market, the CD market is the second largest Japanese money market. The CD market was first established in May 1979, with

\footnotetext{
${ }^{1}$ We thank an anonymous referee for helpful comments on the institutional setting of our domestic rate series.
} 
Table 1

Regulation of Japanese $\mathrm{CD}$ markets

\begin{tabular}{lll}
\hline $\begin{array}{l}\text { Effective } \\
\text { date of change }\end{array}$ & CDs & Term \\
\cline { 2 - 3 } & $\begin{array}{l}\text { Minimum amount } \\
\text { (in millions of yen) }\end{array}$ \\
\hline May 1979 & 500 & $3-6$ month \\
January 1984 & 300 & $3-6$ month \\
April 1985 & 100 & $1-6$ month \\
April 1986 & 100 & $1-$ montb to 1 yr \\
April 1988 & 50 & 2 wk to 2 yr \\
up to now & & \\
\hline
\end{tabular}

Sources: Frankel and Morgan (1992) and Financial Times Management Report (1993).

restrictions on issue size, maturity and negotiability. These restrictions have been gradually relaxed over time (see Table 1). There has been a steady decrease in the minimum issue size, and an increase in the range of maturities. A secondary $C D$ market developed in the first half of 1981, with tanshi companies acting as brokers for lending and borrowing. The secondary $C D$ market is the largest component of the gensaki market. Because the Japanese T-bill market is small size, illiquid, and unseasoned, this study uses $C D$ rates to represent domestic Japanese interest rate levels (see also McKenzie, 1993). Currently, the minimum $\mathrm{CD}$ issue is 50 million yen, with no upper limit.

The remainder of the paper is organized as follows. Section 2 outlines the cointegration methodology that we employ in the paper. Section 3 discusses the empirical results of the cointegration analysis. The sample is divided into earlier and later periods in order to examine the impact of structural change on the interest rate relationship. Section 4 compares the forecasting performance of cointegration analysis, the VAR model and the random walk model. The final section draws conclusions.

\section{Cointegration analysis - methodology}

In regressing one economic time series on another, one frequently observes a high $R^{2}$ and autocorrelated residuals. An unstable covariance matrix precludes regression on levels, but regression on differences can mask an equilibrium relationship. Recognizing this, the possibility of finding spurious significance is minimized by the techniques of cointegration analysis, which we now describe.

A time series is integrated of order one (denoted $I(1)$ ) if it must be first-differenced to induce stationarity. If there exists a linear combination of two or more I(1) series which is itself stationary, the series are said to be cointegrated. 
Table 2

Summary statistics for the Japanese $C D$ and Euroyen markets

\begin{tabular}{lccc}
\hline & Japanese CD & Euroyen & Difference \\
\hline Mean & $5.756^{\mathrm{a}}$ & $5.581^{\mathrm{a}}$ & $0.175^{\mathrm{a}}$ \\
Std. error & 1.400 & 1.407 & 0.101 \\
Skewness & 0.452 & 0.448 & -1.678 \\
Kurtosis & -1.136 & -1.140 & 30.490 \\
\hline
\end{tabular}

Denotes significance at a $5 \%$ level. Read 5.756 as $5.756 \%$.

Consider a $p \times 1$ vector of $I(1)$ variables $X$ which has an autoregressive representation:

$$
X_{t}=\pi_{1} X_{t-1}+\pi_{2} X_{t-2}+\ldots+\pi_{k} X_{t-k}+e_{t} \quad t=1,2 \ldots T
$$

The long-run static equilibrium corresponding to (1) is: ${ }^{2}$

$$
\pi X=0
$$

where the long-run coefficient matrix $\pi$ is defined

$$
\pi=I-\pi_{1}-\pi_{2}-\ldots . .-\pi_{k}
$$

Define two $p \times r$ matrices, $\alpha$ and $\beta$, such that:

$$
\pi=\alpha \beta^{\prime} \text {. }
$$

The rows of $\beta^{\prime}$ form the $r$ distinct cointegrating vectors such that, if $\beta_{i}^{\prime}$ is the $i$ th row of $\beta^{\prime}$ :

$$
\beta_{i}^{\prime} X_{\imath} \sim I(0)
$$

Johansen (1991) demonstrates that the likelihood ratio test statistic for the hypothesis that there are at most $r$ distinct cointegrating vectors is:

$$
L R=-T \sum_{i=r+1}^{p} \ln \left(1-\hat{\lambda}_{i}\right)
$$

where $\hat{\lambda}_{r+1}, \ldots \hat{\lambda}_{p}$ are the $p-r$ smallest squared canonical correlations between the $X_{t-k}$ and $\Delta X_{t}$ series, corrected for the effect of the lagged differences of the $X$ process (for details on the extraction of the estimated $\lambda$, see Johansen, 1988, and Johansen and Juselius, 1990).

\section{Cointegration analysis - Empirical results}

Table 2 reports the summary statistics for the Euroyen and the Japanese $C D$ rates. The results indicate that their difference (i.e., Japanese CD. less Euroyen) is

\footnotetext{
${ }^{2}$ Dynamic steady-state equilibrium involves the addition of a term in the constant vector of steady-state growth rates to Eq. (2). We include this constant term in the empirical analysis.
} 
Table 3

Results of augmented Dickey-Fuller unit root test for Japanese CD and Euroyen rates, 1982-1991

\begin{tabular}{lcl}
\hline$y$ & $b_{1}$ & No. of lags, $k$ used \\
\hline Panel (a): Level & -0.00004 & 10 \\
Japanese CD & $(-0.83)$ & 22 \\
& -0.00006 & 10 \\
Euroyen & $(-1.13)$ & \\
& $(-0.00007$ & 22 \\
& $-0.69)$ & \\
Panel (b): First difference & $(-1.02)$ & 10 \\
Japanese CD & -0.37853 & 22 \\
& $(-10.17)^{\mathrm{a}}$ & \\
& -0.32854 & 10 \\
Euroyen & $(-7.20)^{\mathrm{a}}$ & 22 \\
& -0.90294 & \\
\hline
\end{tabular}

Significant at 5 percent level.

Augmented Dickey-Fuller (ADF) $t$-values are in parentheses. The ADF test is run as follows:

$\Delta Y_{t}=b_{0}+b_{1} Y_{t-1}+\sum \Delta Y_{t-k}+e_{!}$.

$Y$, denotes Japanese $C D$ and Euroyen interest rates. The critical value for 5 percent level is about -2.86 (see Fuller, 1976, p. 373).

statistically significant. On average, the Japanese CD interest rate is about 17.5 basis points higher than the Euroyen deposit rates. Euroyen deposit rates are commonly lower than domestic interest rates, unlike U.S. dollar markets. ${ }^{3}$ This surprising finding is confirmed by the data vendor.

Domestic deposit rates in Japan are higher than Euroyen rates, the opposite of the U.S. experience, which may be due to a perception of lower risk and market imperfections such as regulatory constraints (Fung and Isberg, 1992; Swanson, 1988; Giddy et al., 1979; Grabbe, 1991).

\subsection{A test for cointegration}

Before proceeding with cointegration analysis, it is necessary to ensure that both CDs and Euroyen are $I(1)$. We use the standard Augmented Dickey-Fuller

\footnotetext{
${ }^{3}$ As discussed by Grabbe (1991, p. 255), Eurorates typically exceed domestic rates, possibly because of sovereign and informational risk in the deposit's host country. Examples of this potential include the imposition of currency controls and banking instability.
} 
ation tests, 1984-1993

\begin{tabular}{llll}
\hline & $\mathrm{H}_{0}: r \leq 1$ & $\mathrm{H}_{0}: r \leq 0$ & VAR lag length \\
\hline$\&$ & 1.106 & $45.184^{2}$ & 19 \\
$\mathrm{CD}$ & & & \\
$\mathrm{cal}$ & 9.094 & 20.168 &
\end{tabular}

$s$ significance at 5 percent level.

s: $r$ denotes the maximum number of cointegration vectors. The $5 \%$ critical values are taken nansen and Juselius (1990). The vector autoregressions inciuded constant and seasonal

ure (Dickey and Fuller, 1979) to test for a unit root, i.e., that they are each able 3 reports on this test, using both 10 and 22 lags. The two original lack stationarity, but become stationary after differencing. Thus, these : rate series are $I(1)$. We also find similar (unreported here) results for a ange of autoregressive term lags. The presence of a unit root for both ie $C D$ and Euroyen interest rates is consistent with other studies that e Japanese interest rates (McKenzie, 1993; Takagi, 1988).

Jerform the Johansen analysis described above, one must determine the lag of the VAR. To select the optimal lag, $k$, for cointegration analysis, we Akaike's multiple final prediction error (MFPE). The optimal $k$ is one nimizes

$\operatorname{CFPE}(k)=\left\{\left[\left(1+(m k+1) / N^{m}\right)\right] /\left[(1-(m k+1) / N)^{m}\right]\right\} \operatorname{det}\left(\sum_{k}\right)$,

$V$ is the sample size, $m$ is the number of equations in the model and $\sum_{k}$ is aple covariance matrix of the residuals of the model of order $k$. The im $F P E$ is equivalent to applying an approximate $F$-test (Akaike, 1971). $\tau$ the optimal lag length is determined, we proceed with the cointegration sented in Table 4 . The results suggest that there is one cointegrating vector is Euroyen and Japanese CD rates.

rection of interest rate transmission

a we find that both Euroyen and Japanese $C D$ rates are cointegrated, their ship can be expressed in an error correction model (ECM) (see Engle and ;, 1987; and Johansen, 1988, 1991):

$$
Y_{i}=\alpha Z_{t-1}+\sum_{i=1}^{k} \beta_{i} \Delta Y_{t-i}+\sum_{i=1}^{k} \gamma_{i} \Delta X_{t-i}+e_{t}
$$


Table 5

Tests of international interest rate transmission. The error correction model for the sample period is: $\Delta Y_{t}=\alpha Z_{t-1}+\sum_{i=1}^{19} \beta_{i} \Delta Y_{t-i}+\sum_{i=1}^{19} \gamma_{i} \Delta X_{t-i}+e_{t}$

$\mathrm{H}_{0}$ : all causal variables or cross-market variables, $X$, do not have an important impact on the dependent variable, $Y$, i.e., $\alpha$ and all $\gamma_{\mathrm{i}}$ are equal to zero

\begin{tabular}{lll}
\hline $\begin{array}{l}\text { Dependent } \\
\text { variable }\end{array}$ & $\begin{array}{l}\text { Causal } \\
\text { variable }\end{array}$ & $\begin{array}{l}\mathrm{H}_{0} \text { : Dependent variable is not } \\
\text { caused by the causal variable }\end{array}$ \\
\hline Japanese CD & Euroyen & 10.744 \\
& & $(0.000)$ \\
Euroyen & Japanese CD & 1.575 \\
& & $(0.054)$ \\
\hline
\end{tabular}

These tests have $F$-statistics; thus, the numbers reported are $F$-values. Figures in parentheses ( $p$-values) are marginal significance levels.

where $Y_{t}$ is either a Japanese $\mathrm{CD}$ or a Euroyen rate, $Z_{t-1}$ is the error correction term and $X_{t-i}$ is the cross market variable (e.g., if $Y_{t}$ denotes Japanese CD rate, then $X_{t}$ will be the Euroyen rate); $e_{t}$ is the noise term). $Z_{t-1}$ can be obtained from the regression of $Y_{1}$ on $X_{t}$ (see Granger, 1986).

The Granger-causality of the cross-market variables on the dependent variable is examined by testing whether $\alpha$ and all $\gamma_{i}$ are equal to zero, using a standard $F$-test [for details, see Fung and Isberg, 1992; and Swanson, 1988). ${ }^{4}$

Table 5 shows the empirical results of the Granger-causality tests. The offshore (Euroyen) interest rate strongly Granger-causes domestic rate innovations at conventional significance levels, but the domestic market Granger-causes the offshore market at only the 10 percent level.

The interest rate quotes are not simultaneous in both markets. The Tokyo market closes before the London market, and as a result, can effect the London market on the same day. The daylight (non-overlapping data) problem is common to all studies of international transmission of interest rates. We discussed this problem with the data vendor, who was unable to locate simultaneous data such as mid-session quotes.

When we analyze the effects of domestic market on the offshore market, we used same day quotes. On the other hand, the closing quotes in London cannot affect the same day Tokyo quotes, because the Tokyo market is already closed. Thus there may be a one day lag in causality in this direction. As a result, when we analyze this reverse causality (i.e., the impact of the offshore market on the

\footnotetext{
${ }^{4}$ Since the error correction term, $z_{t-1}$, contains the cross-market variable, $X_{t-1}$, it is appropriate to test its significance. We have also tested all $\gamma_{i}$ without including the error correction term; the results are similar.
} 
Table 6

Ashley tests of parameter stability. The error correction model is subdivided into eight subperiods with $(1,0)$ dummies. For instance, if the hypothesis of stability in $Z_{t-1}$ term is tested, we multiply the 8 dummies with the $Z_{t-1}$ term, and run the regression as follows:

$\Delta Y_{t}=\sum_{j=1}^{8} \alpha_{j} D_{j} Z_{t-1}+\sum_{i=1}^{19} \beta_{i} \Delta Y_{t-i}+\sum_{i=1}^{19} \gamma_{i} \Delta X_{t-i}+e_{t}$.

Then, we test:

$\mathrm{H}_{0}$ : the error correction term is stable over time, i.e., $\alpha(1)=\alpha(2)=\ldots=\alpha(8)$, where $\alpha(j)$ is the $j$ th period coefficient.

In addition, using a similar formulation, we test other hypotheses:

$\mathrm{H}_{0}$ : the own-lagged variables (i.e., $\Delta Y_{t-i}$ which have 19 variables) are stable over time, i.e., $\beta_{i}(1)=\beta_{i}(2)=\ldots=\beta_{i}(8)$, for $i=1,2, \ldots, 7$, where $\beta_{i}(j)$ is the $j$ th period coefficient of the $i$ th variable.

$\mathrm{H}_{0}$ : the cross-market variables (which have 19 variables) are stable over time, i.e., $\gamma_{i}(1)=\gamma_{i}(2)=$ $\ldots=\gamma_{i}(8)$, for $i=1,2, \ldots, 7$, where $\gamma_{i}(j)$ is the $j$ th period coefficient.

$\mathrm{H}_{0}$ : all variables are stable over time

\begin{tabular}{llccc}
\hline Interest & \multicolumn{4}{l}{$\mathrm{H}_{0}:$ coefficients are stable over time } \\
\cline { 2 - 5 } rates & $Z_{t-1}$ & Own-lagged & Cross-market & All variables \\
\hline Japanese & 63.743 & 1.090 & 1.958 & 1.574 \\
$\mathrm{CD}$ & $(0.000)$ & $(0.000)$ & $(0.000)$ & $(0.000)$ \\
Euroyen & 2.899 & 1.149 & 1.008 & 1.259 \\
& $(0.005)$ & $(0.126)$ & $(0.462)$ & $(0.005)$ \\
\hline
\end{tabular}

The statistics are $F$-values. Figures in parentheses ( $p$-vaiues) are marginal significance level.

domestic market), we align the data so that the Euroyen rate on day $t$ is comparable to the Japanese domestic CD rate on day $t+1$.

Our results are different from prior studies which document financial market integration (Fung and Isberg, 1992; Swanson, 1988; Hartman, 1984). These authors found that the domestic market causes changes in the offshore market. Since our Japanese results found that the offshore market has a stronger impact on domestic interest rates than vice versa, we are consistent with Giddy et al. (1979), who demonstrate that Eurodollar rates are more responsive to global competitive forces than to the domestic market.

\subsection{Empirical tests of parameter stability}

Many studies (Jorion, 1992; Campbell and Clarida, 1987) have demonstrated that interest rate behavior is time-varying. In the cross-market transmission of interest rates, Fung and Isberg (1992) and Swanson (1988) indicate that there may be structural shifts from time to time. However, they have not formally tested the changes. In the present study, we searched for the structural change using Ashley's 
Table 7

Subperiod analysis of the interest rate transmission. The error correction model for each period is:

$\Delta Y_{t}=\alpha Z_{t-1}+\sum_{i=1}^{k} \beta_{i} \Delta Y_{t-i}+\sum_{i=1}^{k} \gamma_{i} \Delta X_{t-i}+e_{t}$

$\mathrm{H}_{0}$ : all causal variables or cross market variables, $X$, do not have an important impact on the dependent variable, $Y$, i.e., $\alpha$ and all $\gamma_{i}$ are equal to zero.

\begin{tabular}{llll}
\hline $\begin{array}{l}\text { Dependent } \\
\text { variable }\end{array}$ & $\begin{array}{l}\text { Causal } \\
\text { variable }\end{array}$ & $\begin{array}{l}\mathrm{H}_{0} \text { : cross-market } \\
\text { variables do not } \\
\text { cause dependent } \\
\text { variable }\end{array}$ & $\begin{array}{l}\text { Optimal } \\
\text { lag length }\end{array}$ \\
\hline $\begin{array}{l}\text { Panel (a): First subperiod } \\
\text { Japanese CD }\end{array}$ & Euroyen & $\begin{array}{l}13.942 \\
(0.000)\end{array}$ & 14 \\
Euroyen & Japanese CD & $\begin{array}{c}1.387 \\
(0.146)\end{array}$ & 14 \\
Panel (b): Second subperiod & Euroyen & 3.058 & 10 \\
Japanese CD & Japanese CD & $(0.000)$ & 10 \\
Euroyen & & 5.666 & \\
& & $(0.000)$ & \\
\hline
\end{tabular}

These tests have $F$-statistics; thus, the numbers reported are $F$-values. Figures in parentheses ( $p$-values) are marginal significance levels.

(1984) procedure, a method similar to a Chow test. To test parameter stability, the whole period was split into eight subperiods for our analysis (for details, see Ashley, 1984).

Table 6 reports the results of the parameter stability test. For the Japanese CD equation (i.e., the dependent variable is the $C D$ rate), we found that the error correction term (which represents the long-run relationship), as well as its own lagged variables and cross-market terms are not stable. For the Euroyen equation, we found that only the error correction term changes over time.

This difference between the behavior of Japanese CD and Euroyen interest rates is consistent with the contention that the offshore market is more competitive and has reflected global market forces (Giddy et al., 1979). The domestic market is subject to many regulatory constraints, and its natural tendency to incorporate information from the external market is dampened.

Because Ashley's test indicates that the interest rate relationship is time varying, we split the 1984-1993 sample period into earlier and later periods of roughly equal size, to further examine the impact of the structural change on the interest rate relationship.

Table 7 reports the results of the Granger-causality tests for the two subperiods. The results differ from Fung and Isberg's (1992) results that find only unidirectional impact from the domestic market interest rate to the offshore market in the earlier period, but document two-way causality in the later period. Our results 
indicate that the domestic yen market does not Granger-cause the offshore market in the first subperiod, and has a significant impact on the external market only in the second period. In the first period, the domestic yen market is still isolated from the external market; it becomes more integrated with the global market in the recent years. ${ }^{5}$ These results are consistent with the continuation of deregulation and liberalization in the Japanese money market (McKenzie, 1993; Frankel and Morgan, 1992; Takagi, 1988; Frankel, 1984).

Using the same optimal lag selection procedure, we find that the optimal lag length of 10 in the second period is shorter than in the first period, when 14 is optimal. The shorter lag in the second period confirms that adjustments are more rapid. This finding again supports our conclusion that the domestic and offshore financial market have become more integrated in recent years.

\section{Forecasting}

An issue in cointegration analysis is whether it outperforns the conventional VAR model in forecasting. Engle and Yoo (1987), in a simulated study, suggest that cointegration analysis outperforms the VAR model in a multi-step forecast. However, using cattle futures prices, Bessler and Covey (1991) found that VAR marginally outperforms cointegration analysis in a multi-step forecast.

We compared the forecasting performance for three models: the cointegration model, the VAR model and the random walk model. Following Campbell and Shiller (1988, p. 510) and Bessler and Covey (1991), Eq. (8) can be written in an equivalent form in term of lagged $\Delta Y_{t}$ and $\Delta Z_{t}$ :

$$
\begin{aligned}
& \Delta Y_{t}=\sum_{i=1}^{k} A_{i} \Delta Y_{t-i}+\sum_{i=1}^{k} B_{i} \Delta Z_{t-i}+u_{t} \\
& \Delta Z_{t}=\sum_{i=1}^{k} C_{i} \Delta Y_{t-i}+\sum_{i=1}^{k} D_{i} \Delta Z_{t-i}+v_{t}
\end{aligned}
$$

where $u_{t}$ and $v_{t}$ are white noise residuals, and $A_{i}, B_{i}, C_{i}$ and $D_{i}$ are parameters. ${ }^{6}$ Eqs. (9) and (10) allow multi-steps-ahead forecasts (see Sargent, 1979, p. 268). ${ }^{7}$

In generating the out-of-sample, multi-step forecasts, we used the first twelve hundred observations as a bench mark for estimation. We then used "rolling-over

\footnotetext{
${ }^{5}$ We also used 19 lags for the two-period analysis. The results, similar to other lag rates, indicate that the domestic market does not affect the offshore market in the first period, while there is significant interaction between the domestic and offshore markets in the second period.

${ }^{6}$ To be exact, the number of lags in the lagged $\Delta Z_{t-i}$ terms should be one more than that of the lagged $\Delta Y_{t-i}$ terms. For details, see Campbell and Shiller (1988).

${ }^{7}$ For detailed forecasting procedure, see Bessler and Covey (1991), Campiell and Shiller (1988) and Engle and Yoo (1987).
} 
Table 8

Ratio of mean squared errors for out-of-sample forecasts of Japanese CD and Euroyen rates to random walk, $1984-1993^{2}$

\begin{tabular}{lllll}
\hline & \multicolumn{4}{l}{ Forecast horizon (days) } \\
\cline { 2 - 5 } & 1 & 5 & 15 & 30 \\
\hline Japanese CD model & 0.91754 & 0.96696 & 0.99111 & 0.99926 \\
Cointegration & 0.92228 & 0.97878 & 0.99238 & 1.00020 \\
VAR & & & & \\
Euroyen model & 1.02473 & 0.99957 & 0.99866 & 0.99976 \\
Cointegration & 1.02566 & 0.99848 & 0.99703 & 0.99978 \\
VAR & & & \\
\hline
\end{tabular}

If the number is less than one, it suggests the model (cointegration model or VAR) outperfoms the random walk model.

regressions" to update more current information for forecasting, because of the time varying relationship documented in the previous section. Other benchmarks for the estimation period yield similar results, which are not reported here.

Table 8 reports the ratio of the mean squared error (MSE) of cointegration and VAR forecasts at various horizons between 1 and 30 days for the Euroyen and the CD markets to the MSE of the random walk model. For all horizons in the Euroyen model, except one day, the cointegration model and VAR outperform the random walk model. This result is consistent with the cited literature. As to the Japanese CD market, cointegration analysis also outperforms the random walk model for all horizons; the strongest results are for one day ahead.

Consistent with the relative isolation of the Japanese money market, forecasting is more effective for the domestic CD series. As shown above in the split sample, that isolation is more pronounced in the earlier part of the sample. In other words the ability to forecast was greater when the domestic market was more protected.

When the cointegration model and the VAR model are compared over 15-and 30-day horizons, the cointegration model marginally outperforms the VAR in the Japanese CD equation. These findings are consistent with Engle and Yoo (1987), and indicate that cointegration analysis is a useful tool for future studies of financial time series.

\section{Conclusion}

Using daily Euroyen and Japanese CD interest rates from November 1984 through January 1993, this study examines the relationship between domestic and offshore interest rate markets. We conclude that the domestic market was isolated in the first half of the sample period, while two-way causality characterized the recent years. 
The results also indicate that the interest rate relationship between domestic and offshore markets was time-varying. We find that the adjustment process appears to be faster in recent years, a finding consistent with the belief that international financial markets are becoming more integrated as they are regulated less.

Finally, in comparing the multi-step ahead forecasts for the cointegration model, the VAR model, and the random walk model, we find that the random walk model produces the best one-day ahead forecasts in the Euroyen equation only, while the cointegration model performs best for a longer horizon in both markets. These results suggest that interest rates do not behave like a random walk over a longer horizon. Forecasting future interest rate movements is thus a promising subject for further research. Our results support the use of cointegration analysis for research on financial time series.

\section{Acknowledgements}

The authors would like to thank the two anonymous reviewers for very helpful comments and Miyako Koito for assistance in data collection.

\section{References}

Akaike, H., 1971, Antoregressive model fitting for control, Annals of the Institute of Statistical Mathematics 103-180.

Ashley, R., 1984, A simple test for regression instability, Economic Inquiry (April), 253-268.

Bessler, D.A. and T. Covey, 1991, Cointegration: Some results on U.S. cattle prices, Journal of Futures Markets (April), 461-474.

Campbell, J.Y. and R.J. Shiller, 1988, Interpreting cointegrated models, Joumal of Economic Dynamics and Control 12, 505-522.

Campbell, J.Y. and R.H. Clarida, 1987, The term structure of Euromarket interest rates: An empirical investigation, Journal of Monetary Economics (January), 25-44.

Dickey, D.A. and W.A. Fuller, 1979, Distribution of the estimators for autoregressive time series with a unit root, Joumal of the American Statistical Association (June), 427-31.

Engle, R.F. and C.W.J. Granger, 1987, Co-integration and error correction: Representation, estimation, and testing, Econometrica (March), 251-276.

Engle, R.F. and B.S. Yoo, 1987, Forecasting and testing in co-integrated system, Journal of Econometrics (May), 143-159.

Financial Times Management Report, 1993, Banking in the Far East (Financial Times Business Information, London).

Frankel, A.B. and P.B. Morgan, 1992, Deregulation and competition in Japanese banking, Federal Reserve Bulletin (August), 579-593.

Frankel, J.A., 1984, The yen/dollar agreement: Liberalizing Japanese capital markets (Institute of International Economics).

Fuller, W.A., 1976, Introduction to statistical time series, (John Wiley and Sons, New York).

Fung, H.G. and S. Isberg, 1992, The international transmission of Eurodollar and U.S. interest rates: A cointegration analysis, Journal of Banking and Finance 16, 757-769. 
Giddy, I., G. Dufey and S. Min, 1979, Interest rates in the U.S. and Eurodollar markets, Weltwirtschaftliches Archiv 51-67.

Grabbe, J. Orlin, 1991, Intemational financial markets (Elsevier, New York).

Granger, C.W.J., 1986, Developments in the study of cointegrated economic variables, Oxford Bulletin of Economics and Statistics (August), 213-228.

Hartman, D.G., 1984, The international financial market and U.S. interest rates, Joumal of International Money and Finance (April), 91-103.

Hendershott, P.H., 1967, The structure of international interest rates: The U.S. treasury bill rate and the Eurodollar deposit rate, Joumal of Finance (September), 455-465.

Johansen, S., 1991, Estimation and hypothesis testing of cointegration vectors in Gaussian vector autoregressive models, Econometrica (November), 1551-1580.

Johansen, S., 1988, Statistical analysis of cointegration vectors, Journal of Economic Dynamics and Control 231-254.

Johansen, S. and K. Juselius, 1990, Maximum likelihood estimation and inference on cointegration with applications to the demand for money, Oxford Bulletin of Economics and Statistics 169-210.

Jorion, P., 1992, Term premiums and the integration of the Eurocurrency markets, Journal of International Money and Finance 11 (February), 17-39.

Kaen, F.R. and G.A. Hachey, 1983, Eurocurrency and national money market interest rates, Journal of Money, Credit and Banking (August), 327-338.

Kwack, S.Y., 1971, The structure of international interest rates: An extension of Hendershott's tests, Journal of Finance (September), 897-900.

Levin, J., 1974, The Eurodollar market and the intemational transmission of interest rates, Canadian Journal of Economics (May), 205-224.

McKenzie, C.R., 1993, The money markets in Japan, in: S. Takagi, eds., Japanese capital markets (Blackwell, Oxford).

Sargent, T., 1979, Macroeconomic theory (Academic Press, New York).

Schnitzel, P., 1983, "Testing for the direction of causality between the domestic monetary base and the Eurodollar system," Weltwirtschaftliches Archiv 616-629.

Swanson, P.E., 1988, The international transmission of interest rates: A note on causal relationships between short-term extemal and domestic U.S. dollar returns, Joumal of Banking and Finance 12, - 563-573.

Takagi, S., 1988, Recent developments in Japan's bond and money markets, Journal of the Japanese and International Economies 2, 63-91. 